\title{
Synthesis of the current state of ant knowledge in the Brazilian Amazon: a review
}

In light of the expansion of deforestation in the Amazon and its importance for the balance and maintenance of essential conditions for human well-being research is required to serve as a basis for decision-making regarding the preservation and recovery of Amazonian ecosystems. Considering the difficulty of studying the entire biodiversity of an ecosystem, research has been focused on key groups that can provide reliable and effective ecological information. Among the several existing species that are effective for such studies, ants deserve special attention because of their great ecological importance regarding the performance of key functions, in addition to being sensitive to environmental changes. To synthesize the information available in the literature, this pape presents a bibliographic review of the articles published on ants in the Brazilian Amazon. A total of 177 articles that covered a period of 52 years were found, with a significant increase in publications since the 2000s. Noticeably, there were a large number of studies based in the states of Amazonas and Pará, mainly near the capitals, which emphasizes the need to significantly expand the research collection areas. Most articles were published in the area of ecology, mainly concerning ecological interactions. Despite the advances in studies concerning Amazonian ants, there is still a lack of standardization regarding the sampling methods. In addition, there is a lack of studies that address the functional diversity of this group, which limits our understanding of the ecosystem services that are being lost owing to anthropogenic activities in natural ecosystems.

Keywords: Biodiversity; Insects; Taxonomic indicators; Tropical forest.

\section{Síntese do estado atual do conhecimento das formigas na Amazônia brasileira: uma revisão}

Diante da expansão do desmatamento na Amazônia e sua importância para o equilíbrio e manutenção das condições essenciais ao bem-estar humano, a pesquisa se faz necessária como base para a tomada de decisões quanto à preservação e recuperação dos ecossistemas amazônicos. Considerando a dificuldade de estudar toda a biodiversidade de um ecossistema, a pesquisa tem se concentrado em grupos-chave que podem fornecer informações ecológicas confiáveis e eficazes. Dentre as várias espécies existentes que são eficazes para tais estudos, as formigas merecem atenção especial devido à sua grande importância ecológica no desempenho de funções essenciais, além de serem sensíveis às mudanças ambientais. Para sintetizar as informações disponíveis na literatura, este trabalho apresenta uma revisão bibliográfica dos artigos publicados sobre formigas na Amazônia brasileira. Foram encontrados 177 artigos que abrangiam um período de 52 anos, com aumento significativo de publicações a partir da década de 2000 . Visivelmente, houve um grande número de estudos baseados nos estados do Amazonas e Pará, principalmente no entorno das capitais, o que enfatiza a necessidade de ampliação significativa das áreas de coleta de pesquisas. A maioria dos artigos foi publicada na área de ecologia, principalmente no que diz respeito às interações ecológicas. Apesar dos avanços nos estudos com formigas amazônicas, ainda falta padronização quanto aos métodos de amostragem. Além disso, faltam estudos que abordem a diversidade funcional desse grupo, o que limita nosso entendimento sobre os serviços ecossistêmicos que estão sendo perdidos devido às atividades antrópicas nos ecossistemas naturais.

Palavras-chave: Biodiversidade; Insetos; Indicadores taxonômicos; Floresta tropical.

Topic: Conservação da Biodiversidade

Reviewed anonymously in the process of blind peer.
Received: 09/04/2021

Approved: 08/05/2021
Wully Barreto da Silva (iD)

Instituto Federal de Educação Ciências e Tecnologia do Pará, Brasil http://lattes.cnpq.br/0425197951866054

http://orcid.org/0000-0002-6209-4984

wully bio@hotmail.com

Reinaldo Lucas Cajaiba (iD)

Instituto Federal de Educação Ciências e Tecnologia do Maranhão, Brasil http://lattes.cnpq.br/4059139430516677

http://orcid.org/0000-0003-0176-9201

reinaldocajaiba@hotmail.com

\section{Wilks Barreto da Silva (D)}

Universidade Federal do Pará, Brasiil

http://lattes.cnpq.br/7796978142210344

http://orcid.org/0000-0003-3943-0158

agrobarreto@outlook.com.br
Eduardo Périco

Universidade do Vale do Taquari, Brasil

http://lattes.cnpq.br/4494244221645524

http://orcid.org/0000-0002-2926-6246

Perico.ed@hotmail.com

\section{Referencing this:}

SILVA, W. B.; CAJAIBA, R. L.; SILVA, W. B.; PÉRICO, E.. Synthesis of the current state of ant knowledge in the Brazilian Amazon: a review. Revista Ibero Americana de Ciências Ambientais, v.12, n.5, p.167179, 2021. DOI: http://doi.org/10.6008/CBPC21796858.2021 .005 .0015 


\section{INTRODUCTION}

The Brazilian Legal Amazon (from here on referred to as the Amazon) constitutes over $60 \%$ of the national territory (LIMA et al., 2011), and is renowned worldwide for its high biodiversity and mineral resources (VASCONCELOS et al., 2012; ASSUNÇÃO et al., 2015; MELLO, 2015). In addition, the Amazon performs various ecosystem services at local, regional, and global levels (NUNES et al., 2015), such as carbon sequestration, the regulation of climatic conditions, and the maintenance of freshwater supply (DAVIDSON et al., 2012; AYALA et al., 2016; CASTRO et al., 2016; CAJAIBA et al., 2017).

Despite the international recognition of its importance, the Amazon has suffered the severe degradation of its primary forests over the years (FEARNSIDE, 2006; COPERTINO et al., 2019). In addition, the projections for future forest degradation are not optimistic (BARBER et al., 2014). Data from the National Institute for Space Research (INPE) reveal that deforestation in the Amazon increased by over 34\% between July 2018 and August 2019, with deforestation rates being led by the states of Pará, Mato Grosso, Amazonas, and Rondônia, which account for $84.56 \%$ of the accumulated deforestation that has been recorded in the Amazon so far (INPE, 2020).

Deforestation in the Amazon is the result of pressure from local and economic development, in which forests are replaced by productive land, aiming to serve the domestic and foreign markets (SILVA et al., 2017; SILVA et al., 2019). There are several, often interrelated, contributors to the increase in deforestation. Among the main causes is the implantation of pasture, mainly for cattle raising (CASTELO et al., 2018). Today, Brazil is one of the largest producers of cattle worldwide, much of which is produced in the Amazon (SILVA et al., 2020). Furthermore, the second largest factor contributing to deforestation in the Amazon is agricultural activities, including both family farming, using small and recurring openings in the forests (SOARES et al., 2018; SOTTA et al., 2019), well as large mechanized productions, such as soy (BARONA et al., 2010; KASTENS et al., 2017; SILVA et al., 2017). In addition, anthropogenic activities, such as mining (SONTER et al., 2017), forest fires (LIMA et al., 2020), and hydroelectric plant installations (EMER et al., 2013), have also contributed considerably to Amazonian deforestation. In addition, the wood industry (mostly illegal), which is considered a strong factor contributing towards forest degradation, exerts great pressure on indigenous territories, private properties, and conservation units (MELLO et al., 2017; CELENTANO et al., 2018).

Studies have demonstrated that the conservation of the Amazon and the preservation of its biodiversity are real and challenging concerns, considering that the functioning of the Amazon is fundamental for the balance of essential conditions for human well-being (GARDNER et al., 2013; CAJAIBA et al., 2018). Despite the growing interest in the maintenance of tropical forests, the real conditions of degradation and the subsequent effects on biodiversity as well as ecological functions are still unknown or limited in many regions (MORRIS, 2010; SOLAR et al., 2016; SPILLER et al., 2018). This reinforces the need for studies that carefully analyze the environmental contributions of different landscapes towards the conservation of biodiversity (APOLINÁRIO et al., 2019), which can then be used to estimate the consequences of human actions regarding the loss of ecosystem services (DEL TORO et al., 2012; LIMA et 
al., 2015; TIBCHERANI et al., 2018). Furthermore, this can be used to develop an effective means for restoring deteriorated ecosystems to reestablish the provision of essential ecological services (LAWES et al., 2017).

In this context, studies with key groups are essential for understanding various issues, such as behaviors, ecological relationships, the provision of ecosystem services, patterns of biodiversity (such as richness, species abundance and distribution, death rate, growth, characteristics, and genetic variation), and responses to environmental changes, which can serve as a reference to estimate the degree of conservation or degradation of a given environment (KEMERICH et al., 2014; LIMA et al., 2015). Cortef et al. (1999) and Scott et al. (2006) highlighted characteristics that make certain groups of organisms ecologically effective for studies, including playing an important role in the ecosystem, having a wide distribution, being easy to sample, having a low financial cost, presenting a measurable response to environmental changes, able to reproduce in captivity, and easy to study in situ and in laboratories. In this sense, many groups of animals have been used as a basis for decision making, whether for the recovery of degraded areas or forms of sustainable use (EMER et al., 2013; SEMPRUC et al., 2015; CAJAIBA et al., 2017; BELÉM et al., 2020).

Several studies have demonstrated the importance of incorporating invertebrates in environmental quality investigations (JEREZ-VALLE et al., 2014; CAJAIBA et al., 2017; SPILLER et al., 2018). Among them, ants deserve special attention because of their ecological importance regarding the performance of key functions, such as seed dispersal, herbivory, pollination, nutrient cycling, and soil quality maintenance (DEL TORO, 2012; VICENTE et al., 2016). In addition, ants are potential ecological indicators due to various characteristics, including a high abundance and species richness. Furthermore, specialized taxa are useful for conservation and environmental impact assessments (APOLINÁRIO et al., 2019) as they are ubiquitous (SCHMID et al., 2005; BHARTI et al., 2016), occupy the most varied levels of habitats (from the treetops to the subsoil) (UNDERWOOD et al., 2006; LACAU et al., 2008), and are sensitive to environmental changes (SCHMIDT et al., 2013).

Despite the importance of and countless studies involving this group, there is still a lack of research involving reviews of studies on ants in specific biomes (TIBCHERANI et al., 2018). Therefore, this review aims to create a bibliographic survey of studies on ants in the Brazilian Amazon, to identify: i) general and comprehensive information regarding the publications of scientific articles on ants in the Brazilian Amazon, such as the number of publications, main focuses of studies, and regions/states in the Amazon where the largest amount of research is concentrated, ii) possible knowledge gaps, that is, which aspects of ants in the Amazon still require further study, and iii) the main ecological responses that ants have presented following environmental changes in the Amazon biome.

\section{METHODOLOGY}

During April 2020, a consultation was carried out using popular databases, including Google Scholar, Science Direct, Scielo, Web of Science, and Scopus, without restrictions on the date of publication. 
The following terms in English and Portuguese were used for the search: "Ants AND Amazon/Formiga AND Amazônia", "Formicidae AND Amazon/Formicidae AND Amazônia", and "Hymenoptera AND Amazon/Hymenoptera AND Amazônia". To achieve the greatest possible number of articles, and considering that the name of the biome in which the study was carried out is not always present in the title, keywords, or summary, we also carried out consultations using the names of the states that are entirely or partially within the Amazon biome and, with that, we also used the terms: "Ants AND $n$ ", "Formigas AND $n$ ", "Formicidae AND $n$ ", and "Hymenoptera AND $n$ ", where $n$ represents the states of the Brazilian Legal Amazon (Amapá, Roraima, Acre, Amazonas, Rondônia, Mato Grosso, Maranhão, Pará, and Tocantins).

Then, all articles found during the search were screened by reading the title, summary, and materials and methods, discarding any that did not fit the proposed objective. For this research, we only used articles published in journals, and so monographic works, abstracts of congresses, symposia, theses, and dissertations were excluded. We also discarded works that, despite covering ants, did not have them as the main focus of the study (e.g., surveys on soil macrofauna or anthropogenic impacts on the composition of soil invertebrates), with the justification that the collection method used may not have been the most suitable for collecting ants (SANABRIA et al., 2014).

Data analysis was based on scientometric methods. Therefore, information was extracted from the selected articles, such as: i) year of publication; ii) knowledge area, following the CAPES knowledge area table, which includes: ecology (e.g., general ecology, bioindication, ecological interaction, or sampling method testing), zoology (e.g., taxonomy or forensic entomology), agricultural sciences (e.g., pest control), and genetics (e.g., genes); iii) state in which the research was carried out; iv) collection method (e.g., manual, trap, or bait); v) type of bait; and vi) type of habitat studied (e.g., primary forest, secondary forest, pasture, or monoculture).

\section{RESULTS AND DISCUSSION}

The research resulted in the analysis of 177 articles, conducted over a period of 52 years, with publication dates ranging from 1967 to 2020 (Figure 1). Although the first articles on ants in the Amazon were published in the 1960s, there was a growing interest in studying this group from the 2000s onwards. Of the 177 articles evaluated, only 37 were published in the first 32 years (1967-1999, an average of 1.2 articles per year), while the remaining 140 were published in the last 20 years (average of 6.6 articles per year) (Figure 1). This increase in studies may reflect the great advances that have occurred concerning scientific studies in Brazil (LETA, 2011; TEODORO et al., 2020).

Del Toro et al. (2012), who conducted a review survey concerning the ecosystem services provided by these invertebrates, also highlighted considerable growth over the years. These results are understandable considering that ants are key organisms in ecosystems, performing a variety of ecological functions that are fundamental for good ecosystem functioning (SCHMIDT et al., 2017; RABELLO et al., 2018), making the study of ant ecology important and necessary. In addition, other factors may have contributed to the increase in the studies of ants in the Amazon, including their use as a tool for 
environmental monitoring, which is possible due to their sensitive and rapid responses to environmental changes (BILCE et al., 2011; FERNANDES et al., 2018). Furthermore, ants are one of the most important biological components of the Amazon rainforest, composing a significant part of the animal biomass (DEL TORO et al., 2012; BACCARO et al., 2013).

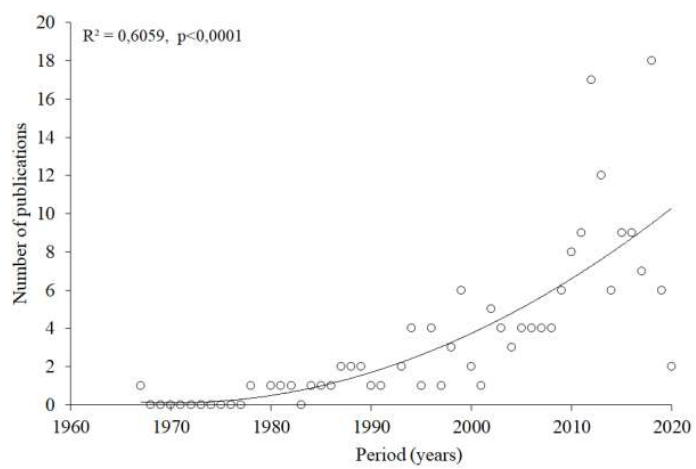

Figure 1: Number of articles published on ants in the Brazilian Amazon per year, with a significant increase since the 2000s. The figure shows a polynomial regression with $R^{2}=0.61$

As for the main areas of knowledge, $76.84 \%$ of the studies examined aimed to study ants in the context of ecological aspects, followed by zoology (18.08\%), agricultural sciences (3.39\%), and genetics (1.69\%). These results show that researchers have a great interest in the ecology of ants in the Brazilian Amazon, mainly concerning ecological interactions (both ant/plant interactions as well as ant/animal interactions) and variation in the ant community (richness, diversity, and species composition) in habitats with different environmental characteristics. The greater number of articles published in the area of ecology can be justified by the fact that it is a very comprehensive area of knowledge, which is divided into several other sub-areas, giving rise to a range of issues that can be studied (OLIVEIRA et al., 2020). Among these sub-areas of ecology, biodiversity and the relationship between organisms and the environment (NICHOLS et al., 2007; GUILHERME et al., 2019) are some of the main focuses of studies carried out in the Brazilian Amazon.

Most articles were published in international journals (58.76\%). Of the articles published in national magazines, $79.10 \%$ were published in English, 19.77\% in Portuguese, and 1.13\% in Spanish. The publication of articles in English enables an international scope, which allows for a larger number of readers, in addition to favoring the internationalization of Brazilian research (RIBAS et al., 2012), with greater chances for citations when compared with articles in Portuguese or Spanish (ANTUNES, 2015; DI BITETTI et al., 2017).

When analyzing the number of articles published per state, Amazonas presented the largest number of studies on ants $(45.20 \%)$, followed by Pará $(22.60 \%)$, while Tocantins presented the lowest number of studies (1.13\%) (Figure 2). This can be explained by at least two hypotheses. First, this is likely impacted by the territorial size of these states, considering that Amazonas and Pará are the first and second-largest states in Brazil, respectively (SOMAIN, 2017; IBGE, 2020). In addition, 100\% of the territory of these states is within the Amazon biome, while only $9 \%$ of the territory of Tocantins is within the biome (IBGE, 2020). Second, the states of Amazonas and Pará host the oldest and most important research centers in the Amazon region. The state of Amazonas has the National Institute for Research in the Amazon 
(INPA), headquartered in Manaus, while the state of Pará has the Museu Paraense Emílio Goeldi, based in the city of Belém. Both institutions aim to study the Amazon biome by rely on the collaboration of researchers and partnerships with national and international institutions (PANZU et al., 2015; LOVEJOY, 2019). In addition, the greater or lesser number of studies in a given region can be determined by various factors, such as the number of researchers, the availability of financial resources, the feasibility of access to areas with the desired characteristics, and the feasibility of sampling the areas (TIBCHERANI et al., 2018).

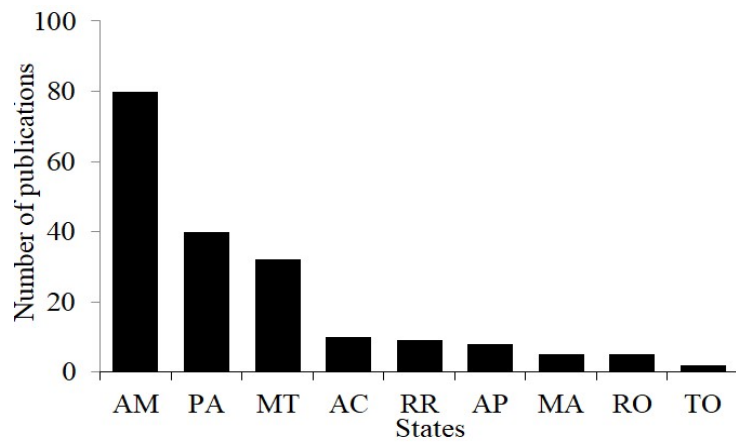

Figure 2: Number of articles published by states in the Brazilian Amazon during the period from 1967 to 2020 . AM (Amazonas), PA (Pará), MT (Mato Grosso), AC (Acre), RR (Roraima), AP (Amapá), MA ( Maranhão), RO (Rondônia) and TO (Tocantins).

Regarding the main habitats that were studied, research was predominately conducted in primary forests $(52.54 \%)$, followed by monoculture $(17.51 \%)$ and secondary forest $(16.59 \%)$ (Table 1$)$. This shows that there is still a lack of studies on ants in this biome, mainly in environments modified by human activities. Furthermore, there is a lack of studies concerning the impacts of changes on the ant community and, consequently, the functioning of the ecosystem. This is highlighted by the fact that habitats that are the most strongly associated with deforestation in the Amazon (PONTES et al., 2016; SPILLER et al., 2018), such as pasture and monoculture, were studied in only $4.52 \%$ and $17.51 \%$ of the articles examined in this research, respectively. Fernandes et al. (2018) highlighted that, considering the increasing changes in the Amazon rainforest landscape resulting from variations in land uses, it is essential to concentrate efforts on areas of human interest and the monitoring of the changes and subsequent impacts on biodiversity.

Table 1: Relative frequency of studies by habitats carried out in the Brazilian Amazon in the period from 1967 to 2020.

\begin{tabular}{ll}
\hline Studied habitat & Relative Frequency (\%) \\
\hline Primary forest/preserved & $52,54 \%$ \\
Monoculture & $17,51 \%$ \\
Secondary forest & $16,59 \%$ \\
Forest fragment & $14,12 \%$ \\
Pasture & $4,52 \%$ \\
Urban area & $2,26 \%$ \\
Forest management area & $2,26 \%$ \\
Area affected by hydroelectric & $2,26 \%$ \\
Agroforestry & $2,82 \%$ \\
Burnt/fire area & $1,69 \%$ \\
Hospital environment & $1,69 \%$ \\
Others & $1,13 \%$ \\
\hline
\end{tabular}

Regarding the collection method, no ants were collected in $25.99 \%$ of the analyzed studies, this was because these studies were based only on observations and/or experiments in situ. Of the 131 publications that collected ants, $81.68 \%$ used only one sampling methodology, while $18.32 \%$ used more than one 
method. Among the methodologies used to capture ants, the most frequently adopted was active manual collection (31.64\%), followed by pitfall traps (22.60\%, of which $10 \%$ used bait) (Figure 3 ) and bait (15.82\%, on paper, plastic, or disposable plates). Souza et al. (2012) indicated that the bait used varies according to the ants' eating habits, which was very evident from the results of this study, where thirteen types of bait were highlighted (sardines, honey, biscuit, honey cake, pork carcass, banana, guava, peanut cream, cassava flour, sugar, beef liver, cheese, and tuna). Of the identified types of bait, the most frequently used were sardines and bee honey, which comprised $57 \%$ and $12.2 \%$ of the articles that used bait, respectively.

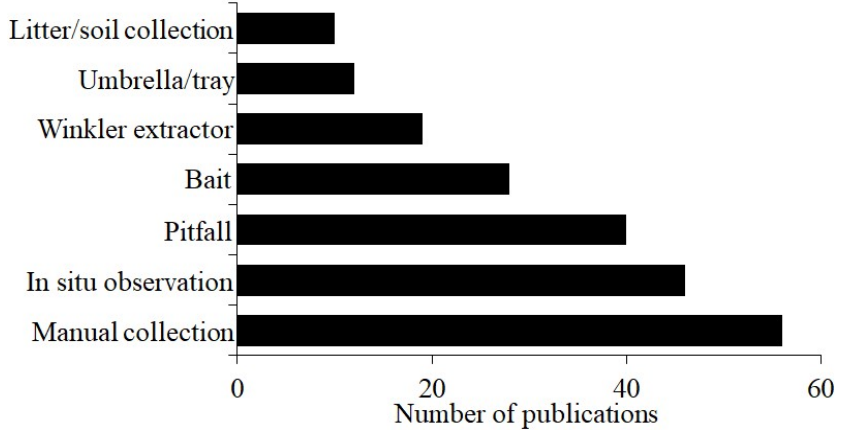

Figure 3: Methods for collecting ants according to the articles published in the Brazilian Amazon from 1967 to 2020.

Manual active collection was the most frequently used method because of the large number of articles focused on ecological interactions. This method is particularly useful when studying the interactions between ants and plants, where capture is carried out via the identification and visualization of the target to collect qualitative and non-quantitative data (ALBUQUERQUE et al., 2009). However, this method requires a great deal of effort and qualified labor, and the results greatly depend upon the skill of the researcher (TEXEIRA, 2012). The use of pitfall traps is widely used in arthropod collections, mainly in ecological fauna surveys, and is effective for collecting ants in the Amazon (SOUZA et al., 2018). Souza et al. (2012), who compared three different methods for collecting ants, concluded that the use of combined techniques (manual and pitfall) obtains a greater species richness. However, when considering each isolated method, the pitfall trap was considered the most effective technique for estimating the richness of ant species in the Amazon in different environments and vegetation types (dense forest, forest in transition, and open environments), as it presented the greatest species richness. Furthermore, in relation to the use of combined techniques or other isolated methods, pitfall traps are economical regarding time and money.

\section{Ant responses to different soil uses in the Brazilian Amazon}

Through our review, we detected several studies that were conducted in the Brazilian Amazon showing that ants respond negatively to anthropogenic pressures. Oliveira et al. (2009), Falcão et al. (2015), Solar et al. (2016) and Oliveira et al., (2019) showed significant differences regarding the species richness and composition between forest habitats and disturbed areas (pasture, forestry, or agriculture), with a lower species richness in modified environments. Similar results were also obtained from an analysis of the consequences of forest fragmentation on the ant community, demonstrating that territorial decreases in 
and isolation of forests can reflect a decrease in the species richness (VASCONCELOS et al., 2006; EMER et al., 2013). It was also found that the frequent burning of forests can negatively affect the richness and diversity of ant species, especially those that inhabit litter and are directly affected by habitat loss, including nesting sites (SANTOS et al., 2008; PAOLUCCI et al., 2016). These results support the hypothesis that less heterogeneous environments with a lower structural diversity (e.g., degraded environments) have a reduced amount of available habitats and food, in addition to being more susceptible to seasonal variations and, therefore, increases in intra- and interspecific competition (OLIVEIRA et al., 2009; BILCE et al., 2011; SOLAR et al., 2016).

On the other hand, forest succession (secondary forests) supports the recolonization of ant communities. Triana et al. (2019), when analyzing the ant community at four levels of forest succession in the Amazon, noticed that there was a significant difference concerning the species richness and frequency between the levels, with a greater richness and frequency observed in the forests with more advanced succession. From this, the authors concluded that the greater the degree of forest succession, the greater the abundance and richness of species. Solar et al. (2016) recognized that primary forests are richer in species compared to non-forest environments, such as pastures and monocultures. However, the recovery of ant diversity in modified forests is not fully understood, even in secondary forests with more advanced stages. One factor that influences the recovery of ant communities in secondary forests is the land use history, since areas that have experienced more intense uses, such as pastures, may take longer to recover than areas abandoned after use for agriculture or selective logging (VASCONCELOS, 1999; HARADA et al., 2013). In addition, the modification of the landscape may cause a reduction in ant-plant interactions via the local co-extinction of plants and mutualistic ants, giving rise to the invasion of opportunistic ants, thus differentiating the ant fauna from disturbed or fragmented forests from undisturbed forests (EMER et al., 2013).

\section{Future challenges and final considerations}

Despite the recent increase in the number of studies on ants in the Brazilian Amazon, research is still in the embryonic stages, since most studies have been conducted close to the state capitals. It is worth noting that the concentration of collection sites, usually around where there are large research centers, also impacts the red lists of states, given that the extinction of a local population of a species can move the conservation status of the species on the list. However, in some cases, this may reflect the lack of geographical coverage of the studies (KEUROGHLIAN et al., 2012). Although the logistics required for the monitoring of remote areas is complex and costly, studies that address the ecological responses of ants to anthropogenic impacts are still required, especially at larger spatial scales and with longer collection periods (VICENTE et al., 2016; CHAVES et al., 2018), which would favor more robust conclusions.

In addition, it is necessary to apply standardized protocols for ant collections, since different collection methodologies make it difficult to compare the results obtained in different studies, leading to erroneous results and, eventually, to erroneous decisions (SILVEIRA et al., 2010; SCHACHAT et al., 2018). 
Thus, more consistent studies in the areas of environmental monitoring and evaluation are required to improve our understanding of the relationship between ants and the environment, to better utilize their function as ecological indicators (MIRANDA et al., 2019; PRINGLE et al., 2019).

In future studies, we suggest that the use of functional diversity and functional characteristics be addressed. Functional diversity, which combines biological diversity and ecosystem functioning (MOUCHET et al., 2010; MUMME et al., 2015), has been increasingly used to assess anthropogenic disorders and restoration programs in different parts of the world (CADOTTE et al., 2011; MONTOYA et al., 2012; CAJAIBA et al., 2020). Thus, the use of the functional approach in future studies is justified by the growing evidence that it is a better predictor of ecosystem processes than taxonomic diversity (DE BELLO et al., 2010; CLARK et al., 2012; GAGIC et al., 2015). This is likely because not all species contribute equally to all functions, that is, the relationship between taxonomic and functional diversity is not predictable or linear (CAJAIBA et al., 2020). Environmental complexity prompts significant variations in the functional diversity of the ant community, through variations in different ant characteristics, such as body size, jaw length, eye size, body biomass, and food guilds. These characteristics provide information concerning the adaptations of foraging strategies in response to environmental variables (GUILHERME et al., 2019). Despite the importance of using functional diversity, only $2.26 \%$ of the articles found in our study used this approach (see: GUILHERME et al., 2019; PRINGLE, 2019; MENEZES et al., 2020). Thus, the use of taxonomic diversity should be complemented with functional diversity to better understand ecosystem processes in regions of high biodiversity, such as the Amazon.

\section{REFERÊNCIAS}

ALBUQUERQUE, E. Z.; DIEHL, E.. Análise faunística das formigas epígeas (Hymenoptera, Formicidae) em campo nativo no Planalto das Araucárias, Rio Grande do Sul. Revista Brasileira de Entomologia, v. 53, n. 3, p. 398-403, 2009. DOI: https://doi.org/10.1590/S0085-56262009000300014

ANTUNES A. A.. How to evaluate scientific production. Revista do Colégio Brasileiro de Cirurgiões, v.42, n.1, p.1719, 2015. DOI: https://doi.org/10.1590/010069912015S01006

APOLINÁRIO, L. C. M. H.; ALMEIDA, A. A.; QUEIROZ, J. M.; VARGAS, A. B.; ALMEIDA, F. S.. Diversity and guilds of ants in different land-use systems in Rio de Janeiro state, Brazil.

Floresta e Ambiente, v.26, n.1, p.01-11. DOI: https://doi.org/10.1590/2179-8087.115217

ASSUNCÃO, J.; GANDOUR, C.; ROCHA, R.. Deforestation slowdown in the Brazilian Amazon: prices or policies? Environment and Development Economics, v.20, p.697-722, 2015. DOI: https://doi.org/10.1017/S1355770X15000078

AYALA, L. M.; EUPEN, M. V.; ZHANG, G.; PÉREZ-SOBA, M.; MARTORANO, L. G.; LISBOA, L. S.; BELTRAO, N. E.. Impact of agricultural expansion onwater footprint in the Amazon under climate change scenarios. Science of the Total Environment, v.569, p.1159-1173, 2016. DOI: https://doi.org/10.1016/j.scitotenv.2016.06.191.

BACCARO, F. B.; ROCHA, I. F.; AGUILA, B. E. G.; SCHIETTI, J.;
EMILIO, T.; PINTO, J. L. P. V.; LIMA, A. P.; MAGNUSSO, W. E. Changes in ground-dwelling ant Functional diversity are correlated with water-table level in an Amazonian terra firme forest. Biotropica, v.45, n.6, p.755-763, 2013. DOI: https://doi.org/10.1111/btp.12055

BARBER, C. P.; COCHRANE, M. A.; SOUZA.; J. R.; C. M.; LAURANCE, W. F.. Roads, deforestation, and the mitigating effect of protected áreas in the Amazon. Biological Conservation, v.177, p.203-209, 2014. DOI: https://doi.org/10.1016/j.biocon.2014.07.004

BARONA, E.; RAMANKUTTY, N. R.; HYMAN, G.; COOMES, O. $T$.. The role of pasture and soybean in deforestation of the Brazilian Amazon. Environmental Research Letters, v.5, p. 01-09, 2010. DOI: https://doi.org/10.1088/17489326/5/2/024002

BELÉM, S. O.; GUIA, B. P.; CAMPBELL, A. J.; MAUÉS, M. M. VIANA, J. H.. Effects of ants (Hymenoptera: formicidae) on flying insect visitor behaviour and fruit production in açaí palm (Euterpe oleracea Martius). Austral Entomology, v.59, n.3, p.612-618, 2020. DOI: https://doi.org/10.1111/aen.12458

BHARTI, H.; BHARTI, M.; PFEIFFER, M.. Ants as bioindicators of ecosystem health in Shivalik Mountains of Himalayas: assessment of species diversity and invasive species. Asian myrmecology, v.8, p.1-15, 2016. DOI: https://doi.org/10.20362/am.008023 
BILCE, J. M.; SILVA, S. A. A.; GALDENCIO, R. R. L.; ROMERA, A F.; BRITES, A.; MARTINS, E. N.. Contribuição ao conhecimento da fauna de formigas (hymenoptera, formicidae) em bordas de fragmentos florestais do norte de Mato Grosso, BRASIL. Revista de Ciências Agro-Ambientais, v.9, n.2, p.191-209, 2011.

CADOTTE, M. W.; CARSCADDEN, K.; MIROTCHNICK, N.. Beyond species: functional diversity and the maintenance of ecological processes and services. Journal of Applied Ecology, v.48, p.1079-1087, 2011. DOI: https://doi.org/10.1111/j.1365-2664.2011.02048

CAJAIBA, R. L.; PÉRICO, E.; SILVA, W. B.; CARON, E.; BUSS, B. C.; DALZOCHIO, M.; SANTOS, M.. Are primary forests irreplaceable for sustaining Neotropical landscapes' biodiversity and functioning? Contributions for restoration using ecological indicators. Land Degradation \& Development, v.31, n. 4, p.508-517, 2020. DOI: https://doi.org/10.1002/ldr.3467

CAJAIBA, R. L.; PÉRICO, E.; DALZOCHIO, M. S.; SILVA, W. B.; BASTOS, R.; CABRAL, J. A.; SANTOS, M.. Does the composition of Scarabaeidae (Coleoptera) communitiesreflect the extent of land use changes in the Brazilian Amazon? Ecological Indicators, v.74, p.285-294, 2017. DOI: https://doi.org/10.1016/j.ecolind.2016.11.018

CAJAIBA, R. L.; PÉRICO, E.; SILVA, W. B.; LEOTE, P.; SANTOS, M.. Are Small Dung Beetles (Aphodiinae) useful for monitoring neotropical forests' ecological status? Lessons from a preliminary case study in the Brazilian Amazon. Forest Ecology and Management, v.429, p.115-123, 2018. DOI: https://doi.org/10.1016/j.foreco.2018.07.005

CAJAIBA, R. L.; PÉRICO, E.; SILVA, W. B.; SANTOS, M.. Seasonal patterns in the diversity of histerid beetles (histeridae) are ecosystem specific? A case in para state, northern Brazil. Applied Ecology and Environmental

Research, v.15, n.4, p.1227-1237, 2017. DOI:

https://doi.org/10.15666/aeer/1504_12271237.

CASTELO, T. B.; ALMEIDA, C. A.; ALMEIDA, O. T.. Governos e mudanças nas políticas de combate ao desmatamento na Amazônia. Revista Ibero-Americana de Economia Ecológica, v.28, n.1, p.125-148, 2018.

CASTRO, A. S.; ANDRADE, D. C.. O custo econômico do desmatamento da Floresta Amazônica brasileira (19882014). Perspectiva Econômica, v.12, n.1, p.1-15, 2016. DOI: https://doi.org/10.4013/pe.2016.121.01.3

CELENTANO, D.; MIRANDA, M. V. C.; MENDONÇA, E. N.; ROUSSEAU, G. X.; MUNIZ, F. H.; LOCH, V. C.; VARGA, I. V. D.; FREITAS, L.; ARAÚJO, P.; NARVAES, I. S.; ADAMI, M.; GOMES, A. R.; RODRIGUES, J. C.; KAHWAGE, C.; PINHEIRO, M.; MARTINS, M. B.. Desmatamento, degradação e violência no "Mosaico Gurupi" - A região mais ameaçada da Amazônia. Estudos Avançados, v.32, n.92, p.315-339. DOI: http://doi.org/10.5935/0103-4014.20180021

CHAVES, V.; NETO, J. J. C.; GOMES, L.. Ocorrência de formigas do gênero Atta (Hymenoptera: Formicidae) no arquipélago do Marajó, norte do Brasil. Revista Brasileira de Zoociências, v.19, n.1, p.137-141.

CLARK, C. M.; FLYNN, D. F. B.; BUTTERFIELD, B. J.; REICH, P. $B$.. Testing the link between functional diversity and ecosystem functioning in a Minnesota grassland experiment.

Plos One, v.7. DOI:

https://doi.org/10.1371//journal.pone.0052821

COPERTINO, M.; PIEDADE, M. T. F.; VIEIRA, I. C. G.; BUSTAMANTE, M.. Desmatamento, fogo e clima estão intimamente conectados na Amazônia. Ciência e Cultura, v.71, n.4, p.4-5. DOI: https://doi.org/10.21800/2317$\underline{66602019000400002}$

CORTEF, J.; VAUFLERY, A. G.; POINSOT-BALAGUER, N.; GOMOT, L.; TEXIER, C.; CLUZEAU, D.. The use of invertebrate soil fauna in monitoring pollutant effects. European Journal of Soil Biology, v.35, n.3, p.115-134, 1999.

DAVIDSON, E. A.; ARAÚJO, A. C.; ARTAXO, P.; BALCH, J. K.; BROWN, I. F.; BUSTAMANTE, M. M. C.; COE MT, D. E.; FRIES, R. S.; KELLER, M.; LONGO, M.; MUNGER, J. W.; SCHROEDER, W.; SOARES-FILHO, B. S.; SOUZA JR, C. M.; WOFSY, S. C.. The Amazon basin in transition. Nature, v.481, p.321-328, 2012. DOI: https://doi.org/10.1038/nature10943

DE BELLO, F.; LAVOREL, S.; DÍAZ, S.; HARRINGTON, R.; CORNELISSEN, J. H. C.; BARDGETT RD, BERG M. P.; WARDLE, D. A.; HARRISON, P. A.. Towards an assessment of multiple ecosystem processes and services via functional traits. Biodiversity and Conservation, v.19, p.2873-2893, 2010. DOI: https://doi.org/10.1007/s10531-010-9850-9

DEL TORO, I.; RIBBONS, R. R.; PELINI, S. L.. The little things that run the world revisited: a review of ant-mediated ecosystem services and disservices (Hymenoptera: Formicidae). Myrmecological News, v.17, p.133-146, 2012.

DI BITETTI, M. S.; FERRERAS, J. A.. Publish (in english) or perish: The effect on citation rate of using languages other than english in scientific publications. Ambio, v.46, p.121127, 2017. DOI: https://doi.org/10.1007/s13280-01600820$\underline{7}$

EMER, C.; VENTICINQUE, E. M.; FONSECA, C. R.. Effects of dam-liduced landscape fragmentation on Amazonian antplant mutualistic networks. Conservation Biology, v.27, n. 4, p.763-773, 2013. DOI: https://doi.org/10.1111/cobi.12045

FALCÃO, J. C. F.; DÁTTILO, W.; IZZO, T. J.. Efficiency of different planted forests in recovering biodiversity and ecological interactions in Brazilian Amazon. Forest Ecology and Management, v.339, p. 105-111, 2015. DOI: https://doi.org/10.1016/i.foreco.2014.12.007

FEARNSIDE, P. M.. Desmatamento na Amazônia: Dinâmica, impactos e controle. Acta Amazonica, v.36, n.3, p.395-400, 2006.

FERNANDES, I. O.; SOUZA, J. L. P.. Dataset of long-term monitoring of ground-dwelling ants (Hymenoptera: Formicidae) in the influence areas of a hydroelectric power plant on the Madeira River in the Amazon Basin. Biodiversity Data Journal, v.6, p.1-29. DOI: https://doi.org/10.3897/BDJ.6.e2437

GAGIC, V.; BARTOMEUS, I.; JONSSON, T.; STEFFAN DEWENTER, I.; EMMERSON, M.; POTTS, S. G.; TSCHARNTKE, T.; WEISSER, W.; BOMMARCO, R.. Functional identity and diversity of animals predict ecosystem functioning better than species-based indices. Proceedings of the Royal Society B: Biological Sciences, v.282, p.20142620-20142620. DOI: https://doi.org/10.1098/rspb.2014.2620 
GARDNER, T. A.; FERREIRA, J.; BARLOW, J.; LEES, A. C.; PARRY, L.; VIEIRA, G. I. C.; BERENGUER, E.; ABRAMOVAY, R.; ALEIXO, A.; ANDRETTI, C.; ARAGÃO, L. E. O. C.; ARAÚJO, I.; ÁVILA, W. S.; BARDGETT, R. D.; BATISTELLA, M.; BEGOTTI, R. A.; BELDINI, T.; BLAS, D. E.; BRAGA, R. F.; BRAGA, D. L.; BRITO, J. G.; CAMARGO, P. B.; SANTOS, F. C.; OLIVEIRA, V. C.; CORDEIRO, A. C. N.; CARDOSO, T. M.; CARVALHO, D. R.; CASTELANI, S. A.; CHAUL, J. C. M.; CERRI, C. E.; COSTA, F. A.; COSTA, C. D. F.; COUDEL, E.; COUTINHO, A. C.; CUNHA, D. A. Á.; DEZINCOURT, J.; DIAS-SILVA, K.; DURIGAN, M.; ESQUERDO, J. C. D. M.; FERES, J.; FERRAZ, S. F. B.; FERREIRA, A. E. M.; FIORINI, A. C.; SILVA, L. V. F.; FRAZÃO, F. S.; GARRETT, R.; GOMES, A. S.; GONÇALVES, K. S.; GUERRERO, J. B.; HAMADA, N.; HUGHES, R. M.; IGLIORI, D. C.; JESUS, E. C.; JUEN, L.; JUNIOR, M.; JUNIOR, J. M. B. O.; JUNIOR, R. C. O.; JUNIOR, C. S.; KAUFMANN, P.; KORASAKI, V.; LEAL, C. G.; LEITÃO, R.; LIMA, N.; ALMEIDA, M. F. L.; LOURIVAL, R.; LOUZADA, J.; NALLY, R. M.; MARCHAND, S.; MAUÉS, M. M.; MOREIRA, F. M. S.; MORSELLO, C.; MOURA, N.; NESSIMIAN, J.; NUNES, S.; OLIVEIRA, V. H. F.; PARDINI, R.; PEREIRA, H. C.; POMPEU, P. S.; RIBAS, C. R.; ROSSETTI, F.; SCHMIDT, V.; SILVA, R.; SILVA, R. C. V. M.; SILVA, T. F. M. R.; SILVEIRA, J.; SIQUEIRA, J. V.; CARVALHO, T. S.; SOLAR, R. R. C.; TANCREDI, N. S. H.; THOMSON, J. R.; TORRES, P. C.; VAZ-DE-MELLO, F. Z.; VEIGA, R. C. S.; VENTURIERI, A.; VIANA, C.; WEINHOLD, D.; ZANETTI, R.; ZUANON, J. A social and ecological assessment of tropical land uses at multiple scales: The Sustainable Amazon Network. Philosophical Transactions of The Royal Society B, v.368, p.1-11, 2013. DOI: https://doi.org/10.1098/rstb.2012.0166

GUILHERME, D. R.; SOUZA, J. L. P.; FRANKLIN, E.; PEQUENO, P. A. C. L.; CHAGAS, A. C.; BACCARO, F. B.. Can environmental complexity predict functional trait composition of ground-dwelling ant assemblages? A test across the Amazon Basin. Acta Oecologica, v.99, 2019. DOI: https://doi.org/10.1016/i.actao.2019.05.004

HARADA, A. Y.; FARIAS, P. R. S.; LOPES, L. F. C.; SILVA, A. G.; BRANDÃO, A. D. S.. Assessment of ant communities in secondary forest in the eastern Amazon. Comunicata Scientiae, v.4, p.186-194, 2013.

IBGE. Território. Rio de Janeiro, 2020.

INPE. A taxa consolidada de desmatamento por corte raso para os nove estados da Amazônia Legal (AC, AM, AP, MA, MT, PA, RO, RR e TO) em 2019 é de 10.129 km2. São Paulo, 2020.

JEREZ-VALLE, C.; GARCÍA, P. A.; CAMPOS, M.; PASCUAL, F.. A simple bioindication method to discriminate olive orchardmanagement types using the soil arthropod fauna. Applied Soil Ecolog, v.76, p.42-51, 2014. DOI: https://doi.org/10.1016/j.apsoil.2013.12.007

KASTEN, J. H., BROW, J. C., COUTINHO A. C., BISHOP C. R., ESQUERDO, J. C. M.. Soy moratorium impacts on soybean and deforestation dynamics in Mato Grosso, Brazil. Plos One, v.12, n.4, p.01-21, 2017. DOI:

https://doi.org/10.1371/journal.pone.0176168

KEMERICH, P. D. C.; RITTER, L. G.; BORBA, W. F.. Indicadores de sustentabilidade ambiental: métodos e aplicações.

Revista do Centro do Ciências Naturais e Exatas da UFSM, v.13, n.5, p.3723-3736, 2014. DOI:

https://doi.org/10.5902/2236130814411
KEUROGHLIAN, A.; DESBIEZ, A. L. J.; BEISIEGEL, B.; L.; MEDICI, E. P.; GATTI, A.; PONTES, A. R. M.; CAMPOS, C. B.; TÓFOLI, C. F.; MORAES JUNIOR, E. A.; AZEVEDO, F. C.; PINHO, G. M.; CORDEIRO, J. L. P.; SANTOS JÚNIOR, T. S.; MORAIS, A. A.; MANGINI, P. R.; FLESHER, K.; RODRIGUES, L. F.; ALMEIDA, L. B.. Avaliação do Risco de Extinção do Queixada Tayassu pecari Link, 1795, no Brasil. Biodiversidade Brasileira, v.2, p. 84-102, 2012.

LACAU, L. S. R.; ZANETTI, R.; DELABIE, J. H. C.; MARINHO, C. G. S.; SCHLINDWEIN, M. N.; LACAU, S.; NASCIMENTO, L. S. R.. Respostas das guildas de formigas (hymenoptera: formicidae) a Práticas silviculturais em plantio de eucaliptos. Agrotrópica, v.20, p.61-72, 2008.

LAWES, M. J.; MOORE, A. M.; ANDERSEN, A. N.; PREECE, N. D.; FRANKLIN, D. C.. Ants as ecological indicators of rainforest restoration: Community convergence and the development of an ant forest indicator index in the Australian wet tropics. Ecology and Evolution, v.7, n.20, p. 8442-8455, 2017. DOI: https://doi.org/10.1002/ece3.2992

LETA, J.. Indicadores de desempenho, ciência brasileira e as coberturas das bases informacionais. Revista USP, v.89, p.62-77, 2011.

LIMA, A. C.; PAULETTO, D.; ANDRADE, J. C. G.. Registros de incêndios na região metropolitana de Santarém/PA no período de 2012 a 2016. Revista Ibero Americana de Ciências Ambientais, v.11, p.9-18, 2020. DOI: https://doi.org/10.6008/CBPC2179-6858.2020.001.0002

LIMA, M.; SKUTSCH, M.; COSTA, G. M.. Deforestation and the Social Impacts of Soy for Biodiesel Perspectives of Farmers in theSouth Brazilian Amazon. Ecology and Society, v.16, p.1-17, 2011. DOI: https://doi.org/10.5751/ES-04366160404

LIMA, P. A. F.; PACHÊCO, B. S.; SOUSA, S. R.; GATTO, A.; AQUINO, F. G.; ALBUQUERQUE, L. B.. Indicadores ecológicos: ferramentas para o monitoramento do processo de restauração ecológica. Embrapa cerrados, p.11-46, 2015.

LOVEJOY, T.. A terra da canela e ouro: 500 anos de ciência e exploração na Amazônia. In: GALÚCIO, A. V.; PRUDENTE, A. L.. Museu Goeldi: 150 anos de ciência na Amazônia. Belém: Museu Emílio Goeldi, 2019.

MELLO, A. F.. Dilemas e desafios do desenvolvimento sustentável da Amazônia: O caso brasileiro. Revista Crítica de Ciências Sociais, v.107, p.91-108, 2015. DOI: https://doi.org/10.4000/rccs.6025

MELLO, N. G. R.; ARTAXO, P.. Evolução do Plano de Ação para Prevenção e Controle do Desmatamento na Amazônia Legal. Revista do Instituto de Estudos Brasileiros, v.66, p.108-129, 2017. DOI: https://doi.org/10.11606/issn.2316901X.v0i66p108-129

MENEZES, A. S.; SCHMIDT, F. A.. Mechanisms of species coexistence and functional diversity of ant assemblages in forest and pasture habitats in southwestern Brazilian Amazon. Sociobiology, v.67, n.1, p.33-40, 2020. DOI: https://doi.org/10.11606/issn.2316-901X.v0i66p108-129

MIRANDA, P. N. J.; RIBEIRO, E. L. S.; LUNA, P.; BRASIL, I.; DELABIE, J. H. C.; DÁTTILO, W.; MIRANDA, P. N.; RIBEIRO, J. E. L. S.; LUNA, P.; BRASIL, I.; DELABIE, J. H. C.; DÁTTILO, W.. The dilemma of binary or weighted data in interaction 
networks. Ecological Complexity, v.38, p.1-10, 2019. DOI: https://doi.org/10.1016/i.ecocom.2018.12.006

MONTOYA, D. R.; MEMMOTT, J.. Emerging perspectives in the restoration of biodiversity-based ecosystem services. Ecology and Evolution, v.27, p.666-672, 2012. DOI: https://doi.org/10.1016/i.tree.2012.07.004

MORRIS, R. J.. Anthropogenic impacts on tropical forest biodiversity: a network structure and ecosystem functioning perspective. Philosophical Transactions of The Royal Society B, v.365, p.3709-3718, 2010. DOI: https://doi.org/10.1098/rstb.2010.0273

MOUCHET, M. A.; VILLÉGER, S.; MASON, N. W. H.; MOUILLOT, D.. Functional diversity measures: An overview of their redundancy and their ability to discriminate community assembly rules. Functional Ecology, v.24, p.867876, 2010. DOI: https://doi.org/10.1111/j.1365$\underline{2435.2010 .01695 . x}$

MUMME, S.; JOCHUM, M.; BROSE, U.; HANEDA, N. F.; BARNES, A. D.. Functional diversity and stability of litterinvertebrate communities following land-use change in Sumatra, Indonesia. Biological Conservation, v.191, p.750758, 2015. DOI: https://doi.org/10.1016/j.biocon.2015.08

NICHOLS, E.; LARSEN, T.; SPECTOR, S.; DAVIS, A. L.; ESCOBAR, F.; FAVILA, M.; VULINEC, K.; NETWORK, S. R.. Global dung beetle response to tropical forest modification and fragmentation: A quantitative literature review and meta-analysis. Biological Conservation, v.137, p.1-1 9, 2007. DOI: https://doi.org/10.1016/j.biocon.2007.01.023

NUNES, S. S.; BARLOW, J.; GARDNER, T. A.; SIQUEIRA, J. V.; SALES, M. R.; SOUZA JR, C. M.. A 22 year assessment of deforestation and restoration in riparian forests inthe eastern Brazilian Amazon. Environmental Conservation, v.42, n.3, 2015, p.193-203. DOI: https://doi.org/10.1017/S0376892914000356

OLIVEIRA, A. B. S.; SCHMIDT, F. A.. Ant assemblages of Brazil nut trees Bertholletia excelsa in forest and pasture habitats in the Southwestern Brazilian Amazon. Biodiversity and Conservation, v.28, p.329-344, 2019. DOI: https://doi.org/10.1007/s10531-018-1657-0

OLIVEIRA, M. A.; DELLA, L. T. M. C.; MARINHO, C. G. S.; DELABIE, J. H. C.; MORATO, E. F.. Ant (Hymenoptera: Formicidae) Diversity in an Area of the Amazon Forest in Acre Brazil. Sociobiology, v.54, n.1, p.1-26, 2009.

OLIVEIRA, M. R. F.; COSTA, C.; BENEDITO, E.. Trends and gaps in scientific production on freshwater sponges. Oecologia Australis, v.24, n.1, p.61-75, 2020. DOI: https://doi.org/10.4257/oeco.2020.2401.05

PANZU, A. N. S.; SILVA FILHO, E. G.. A construção do conhecimento no instituto nacional de pesquisas da Amazônia - INPA, por meio de suas expedições científicas, (1954-1975), Oficina do Historiador, v.8, n.2, p.7-23, 2015. DOI: https://doi.org/10.15448/2178-3748.2015.2.21553

PAOLUCCI, L. N.; MAIA, M. L. B.; SOLAR, R. R. C.; CAMPOS, R. I.; SCHOEREDER, J. H.; ANDERSEN, A. N.. Fire in the Amazon: impact of experimental fuel addition on responses of ants and their interactions with myrmecochorous seeds.

Oecologia, v.182, p.335-346. DOI:

https://doi.org/10.1007/s00442-016-3638-x
PONTES, R. V. R.; NORONHA, M. C.; PONTES, K. R. M.. Desflorestamento no sul do Amazonas: Embate entre o desenvolvimento econômico e a conservação ambiental. Parcerias estatísticas, v.21, n.42, p.61-88, 2016.

PRINGLE, E. G.; SANTOS, T. F.; GONÇALVES, M. S.; HAWES, J. E.; PERES, C. A.; BACCARO, F. B.. Arboreal ant abundance tracks primary productivity in na Amazonian whitewater river system. Ecosphere, v.10, n.10, 2019. DOI: https://doi.org/10.1002/ecs2.2902

RABELLO, A. M.; PARR, C. L.; QUEIROZ, A. C. M.; BRAGA, D. L.; SANTIAGO, G. S.; RIBAS, C. R.. Habitat attribute similaritiesreduce impacts of land-use conversion on seed removal. Biotropica, v.50, n.1, p.39-49, 2018. DOI: https://doi.org/10.1111/btp.12506

RIBAS, C. R.; CAMPOS, R. B. F.; SCHMIDT, F. A.; SOLAR, R. R. C.. Ants as Indicators in Brazil: A Review with Suggestions to Improve the Use of Ants in EnvironmentalMonitoring Programs. Psyche, v.12, p.1-24, 2012. DOI: https://doi.org/10.1155/2012/636749

SANABRIA, C.; LAVELLE, P.; FONTE, S. J.. Ants as indicators of soil-based ecosystem services in agroecosystems of the Colombian Lianos. Applied Soil Ecology, v.84, p.24-30, 2014. DOI: https://doi.org/10.1016/j.apsoil.2014.07.001

SANTOS, J. C.; DELABIE, J. H. C.; FERNANDES, G. W.. A 15year post evaluation of the fire effects on ant community in an area of Amazonian forest. Revista Brasileira de Entomologia, v.52, n.1, p.82-87, 2008.

SCHACHAT, S. R.; LABANDEIRA, C. C.; MACCRACKEN, A. S.. The importance of sampling standardization for comparisons of insect herbivory in deep time: a case study from the late Palaeozoic. Royal Society open Science, v.5, p.1-15, 2018. DOI: https://doi.org/1098/rsos.171991

SCHMIDT, F. A.; RIBAS, C. R.; SCHOEREDER, J. H.. How predictable is the response of ant assemblages to natural forest recovery? Implications for their use as bioindicators. Ecological Indicators, v.24, p.158-166, 2013. DOI: https://doi.org/10.1016/j.ecolind.2012.05.031

SCHMIDT, F. A.; SCHOEREDER, J. H.; CAETANO, M. D. N.. Ant assemblage and morphological traits differ in response to soil compaction. Insectes Sociaux, v.64, p.219-225, 2017. DOI: https://doi.org/10.1007/s00040-016-0532-9

SCHMIDT, K.; CORBETTA, R.; CAMARGO, A. J. A.. Formigas (Hymenoptera: Formicidae) da Ilha João da Cunha, SC: composição e diversidade. Biotemas, v.18, n.1, p.57-71, 2005.

SCOTT, A. G.; OXFORD, G. S.; SELDEN, P. A.. Epigeic spiders as ecological indicators of conservation value for peat bogs. Biological Conservation, v.127, p.420-428, 2006. DOI: https://doi.org/10.1016/j.biocon.2005.09.001

SEMPRUCCI, F.; LOSI, V.; MORENO, M.. A review of Italian research on free-living marine nematodes and the future perspectives on their use as Ecological Indicators (Ecolnds). Mediterranean Marine Science, v.16, n.2, p.352-365, 2015. DOI: https://doi.org/10.12681/mms.1072

SILVA, J. R. C. A.; LIMA, M.. Soy moratorium in Mato Grosso: 
Deforestation undermines the agreement. Land Use Policy, v.71, p.540-542, 2017. DOI:

https://doi.org/10.1016/i.landusepol.2017.11.011

SILVA, C. A. A. C.; OLIVEIRA, K. A.; CASTRO, M. P. P.; OLIVEIRA, A. K. S.; ALMEIDA, E. I. B.; SOUSA, W. S.. Análise da dinâmica no uso da terra maranhense na Amazônia Legal.

Revista Verde, v.14, n.3, p.443-452, 2019. DOI:

https://doi.org/10.18378/rvads.v14i3.6550

SILVA, J. M. C.; PRASAD, S.; DINIZ-FILHO, J. A. F.. The impact of deforestation, urbanization, public investments, and agriculture on human welfare in the Brazilian Amazonia.

Land Use Policy, v.65, p.135-142, 2017. DOI:

https://doi.org/10.1016/j.landusepol.2017.04.003

SILVA, T. T. A.; SILVA, F. M.; SANTOS, F. A. G.. Pecuária bovina de corte brasileira: Sua contribuição para o aquecimento global nos últimos 20 anos e o desrespeito aos princípios ambientais constitucionais. Revista Jurídica LusoBrasileira, v.6, n.1, p.1285-1317, 2020.

SILVEIRA, L. S.; BEISIEGEL, B. M.; CURCIO, F. F.; VALDUJO, P. H.; DIXO, M.; VERDADE, V. K.; MATTOX, G. M. T.; CUNNINGHAM, P. T. M.. Para que servem os inventários de fauna? Estudos avançados, v.24, p.173-207, 2010.

SOARES, F. M. H. C.; SANTOS, B. N. E.; ASSIS, S. C.; MARTINS, C. Y. E.. Impacto dos assentamentos rurais no desmatamento da Amazônia. Mercator, v.17, p.1-20, 2018. DOI: https://doi.org/10.4215/rm2018.e17009

SOLAR, R. R. C.; CHAUL, J. C. M.; MAUÉS, M.; SCHOEREDER, J. H.. A Quantitative Baseline of Ants and Orchid Bees in Human-Modified Amazonian Landscapes in Paragominas, Pará, Brazil. Sociobiology, v.63, n.3, p.25-940, 2016. DOI: https://doi.org/10.13102/sociobiology.v63i3.1052

SOLAR, R. R. C.; BARLOW, J.; ANDERSEN, A. N.; SCHOEREDER, J. H.; BERENGUER, E.; FERREIRA, J. N.; GARDNER.; T. A.. Biodiversity consequences of land-use change and forest disturbance in the Amazon: a multi-scale assessment using ant communities. Biological Conservation, v.197, p.98-107, 2016. DOI: https://doi.org/10.1016/j.biocon.2016.03.005

SOMAIN, R.. Estados brasileiros e países do mundo, Confins, v.22, p.1-5. DOI: https://doi.org/10.4000/confins.9907

SONTER, L. J.; HERRERA, D.; BARRETT, D. J.; GALFORD, G. L.; MORAN, C. J.; SOARES-FILHO, B. S.. Mining drives extensive deforestation in the Brazilian Amazon. Nature Communications, v.8, p.01-07, 2017. DOI: https://doi.org/10.1038/s41467-017-00557-w

SOTTA, E. D.; LIMA, R. C.; RAMOS, M. B. B.; SILVA, B.; M.; S.; APARÍCIO, P. S.. Amazônia Oriental, sistemas alternativos ao de corte e queima utilizados na agricultura de subsistência. Revista Arquivos Científicos (IMMES), v.2, n.2, p.64-73, 2019.

SOUZA, J. L. P.; BACCARO, F. B.; PEQUENO, P. A. C. L.; FRANKLIN, E.; MAGNUSSON, W. E.. Effectiveness of genera as a higher-taxon substitute for species in ant biodiversity analyses is not affected by sampling technique. Biodiversity and Conservation, v.27, p.3425-3445, 2018. DOI: https://doi.org/10.1007/s10531-018-1607-x

SOUZA, J. L. P.; BACCARO, F. B.; LANDEIRO, V. L.; FRANKLIN, E.; MAGNUSSON, E.. Trade-offs between complementarity and redundancy in the use of diferente sampling techniques for ground-dwelling ant assemblages. Applied Soil Ecology, v.56, p.63-73. DOI: https://doi.org/10.1016/j.apsoil.2012.01.004

SPILLER, M. S., SPILLER, C., GARLET, T.. Arthropod bioindicators of environmental quality. Revista Agro@mbiente On-line, v.12, n.1, p.41-57, 2018. DOI: https://doi.org/10.18227/1982-8470ragro.v12i1.4516

TEODORO, L. O.; SOUZA, A. L. B. N.; SILVA, T. A. C.; FRANCO, P. L. B. N.; MORAIS, A. R.. Padrões e tendências da produção científica sobre anuros da região centro-oeste do Brasil. Oecologia Austrais, 24, p.1-10, 2020. DOI: https://doi.org/10.4257/oeco.2020.2401.01

TEXEIRA, F. M.. Técnicas de captura de Hymenoptera (Insecta). Vértices, v.14, n.1, p.169-198, 2012.

TIBCHERANI, M.; NACAGAVA, V. A. F.; ARANDA, R.; MELLO, R. L.. Review of Ants (Hymenoptera: Formicidae) as bioindicators in the Brazilian Savanna. Sociobiology, v.65, n.2, p.112-129, 2018. DOI:

https://doi.org/10.13102/sociobiology.v65i2.2048

TRIANA, S. P.; ROUSSEAU, G. X.; GUTIÉRREZ, J. A. M.; PIEDADE, A. R.; BRAUN, H.. ¿'Refleja Formicidae el impacto de la degradación de los bosques ribereños en la Amazonía Oriental?. Biologia Tropical, v.67, n.4, p.850-860, 2019.

UNDERWOOD, E. C.; FISHER, B. L.. The role of ants in conservation monitoring: If, when, and how. Biological Conervation, v.132, p.166-182, 2006. DOI: https://doi.org/10.1016/j.biocon.2006.03.022

VASCONCELOS, E. R.; FREITAS, N. M. S.. Amazônia, entre um olhar científico e um olhar amazônida: Pistas para um processo educativo que inicia com as preocupações locais. Revista Eletrônica do Mestrado em Educação Ambiental, v.2, p.01-16, 2012.

VASCONCELOS, H. L.. Effects of forest disturbance on the structure of ground-foraging ant communities in central Amazonia. Biodiversity and Conservation, v.8, p.409-420, 1999.

VASCONCELOS, H. L.; VILHENA, J. M. S.; MAGNUSSON, W. E.; ALBERNAZ, A. L. K. M.. Long-term effects of forest fragmentation on Amazonian ant Communities. Journal of Biogeography, v.33, n.8, p.1348-1356. DOI: https://doi.org/1 0.1111/j.1365-2699.2006.01516.x

VICENTE, R. E.; PRADO, L. P.; IZZO, T. J.. Amazon Rainforest Ant-Fauna of Parque Estadual do Cristalino: Understory and Ground-Dwelling Ants. Sociobiology, v.63, n.3, p.894-908. DOI: https://doi.org/10.13102/sociobiology.v63i3.1043

A CBPC - Companhia Brasileira de Produção Científica (CNPJ: 11.221.422/0001-03) detém os direitos materiais desta publicação. Os direitos referem-se à publicação do trabalho em qualquer parte do mundo, incluindo os direitos às renovac̃os, expansões e disseminã̃es da contribuic̃a bem como outros direitos subsidiários. Todos os trabalhos publicados eletronicamente poderão posteriormente ser publicados em coletâneas impressas sob coordenação da Sustenere Publishing da Companhia Brasileira de Produção Científica e seus parceiros autorizados. Os (as) autores (as) preservam os direitos autorais, mas não têm permissão para a publicação da contribuição em outro meio, impresso ou digital, em português ou em tradução. 